\title{
WIDEOTRENING KOMUNIKACJI ĆWIERĆ WIEKU PÓŹNIEJ. ROZWÓJ VIDEO HOME TRAINING/ VIDEO INTERACTION GUIDANCE W PRACY SOCJALNEJ, PSYCHOLOGII, PEDAGOGICE I MEDYCYNIE
}

\begin{abstract}
Video Home Training/Video Interaction Guidance twenty-five later. VHT/VIG development in social work, psychology, education and medicine

Video Home Training (or Video Interaction Guidance, or Video Enhanced Reflective Practice) has a twenty five years of tradition in Western social services (especially the Netherlands, United Kingdom and Germany). In this article I want to present the development of this method in the last decades. It found application in the area of work with children and families, disabled people, peer groups, education al psychology and supervision of students and professionals. In the past, Polish social workers also benefited from VHT, which is why it is worth recalling his method and making it more popular and applied again.
\end{abstract}

Key words: Video Home Training, Video Interaction Guidance, family assistance, social work, supervision

\section{Wprowadzenie}

Ćwierć wieku to dobra okazja do refleksji nad przeszłością i teraźniejszością pracy socjalnej. Edukacja pracy socjalnej na poziomie uniwersyteckim w Polsce zaczęła się utrwalać w połowie lat 90 . XX wieku. Studia pracy socjalnej jako specjalności rozpoczęły się na wydziałach socjologii, polityki społecznej, pedagogiki czy politologii pod koniec lat 80 . i na początku lat 90 . XX wieku.

W 1994 roku rozpoczęto wydawanie „Zeszytów Pracy Socjalnej” (ZPS) w Instytucie Socjologii Uniwersytetu Jagiellońskiego. Miały one służyć pomocą studentom jako materiały zawierające współczesne teksty o amerykańskiej i brytyjskiej pracy socjalnej oraz bieżące prace empiryczne realizowane w Polsce.

Nie sposób przecenić powstania „Zeszytów Pracy Socjalnej” dla ugruntowania pracy socjalnej jako dyscypliny akademickiej. Ich twórcą był Krzysztof Frysztacki, ówczesny 
dyrektor Instytutu Socjologii U i inicjator powstania zaocznych socjologicznych studiów magisterskich o specjalności pracy socjalnej w roku akademickim 1988/1989. Pierwszy numer „Zeszytów” ukazał się dwadzieścia pięć lat temu (w 1994 roku) i zawierał fragmenty haseł z amerykańskiej Encyklopedii Pracy Socjalnej. W kolejnych latach „Zeszyty Pracy Socjalnej" umożliwily dostęp do podstawowej literatury przedmiotu (między innymi prace Zofii Butrym czy Francesco Villi) oraz aktualnych prac badawczych w dziedzinie pracy socjalnej (monografie pracowników Zakładu Socjologii Stosowanej i Pracy Socjalnej Instytutu Socjologii Uniwersytetu Jagiellońskiego). Rozpoczęcie wydawania ZPS oznaczało, że edukacja w polskiej pracy socjalnej podąża za najnowocześniejszymi wzorcami wywodzącymi się z ośrodków o najdłuższej tradycji i największym potencjale naukowym, czyli amerykańskiej i brytyjskiej pracy socjalnej. W realizacji tego celu pomagała intensywna współpraca między Instytutem Socjologii UJ a School of Social Work Ohio State University (Columbus, Ohio), Center on Philantrophy Indiana University (Indianapolis, Indiana), a w następnych latach z Evangelische Fachhochschule w Berlinie (Niemcy).

Mniej więcej w tym samym czasie rozpoczęły się przygotowania do zorganizowania szkolenia Wideotreningu Komunikacji (WK) ${ }^{1}$. Główną rolę w tym przedsięwzięciu odegrał Jan van der Does, psychiatra dzieci i młodzieży, który uzyskał odpowiednie środki i przygotował sprzętową oraz osobową infrastrukturę przedsięwzięcia². Szkolenia były prowadzone przez holenderskich trenerów (na początku Marij Eliens, Aba Molevijka i przede wszystkim Irmę Donders) i pozwoliły wykształcić kadrę pierwszych trenerów WK w Krakowie (Reczek 2001). Kolejne szkolenia odbyły się w wielu innych polskich miastach, a następnie w krajach sąsiedzkich (na Słowacji i Ukrainie).

Wdrożenie WK do polskiego systemu pomocy społecznej i edukacji rozpoczęło się w połowie lat 90. XX wieku. Był to okres kształtowania się nowego ustroju gospodarczego i społecznego oraz formowania się nowego modelu polityki i pomocy społecznej. Poznanie metody WK przez uczestników polskich kursów poszerzyło instrumentarium polskiej pracy socjalnej i pomogło w jej unowocześnieniu. Stało się okazją do styczności z praktyką najbardziej rozwiniętych technologicznie i organizacyjnie ośrodków europejskich (w Niderlandach i Wielkiej Brytanii).

Mało kto spodziewał się wtedy, że w niedługim czasie prawie każdy dorosły Polak będzie nagrywał i odtwarzał filmy wideo, co więcej - będzie nosił przy sobie urządzenie, które to umożliwia. Rewolucja technologiczna w mediach przyczyniła się do ułatwienia pracy wideotrenerów komunikacji. Zamiast masywnego i ciężkiego sprzętu używanego w latach 80. i 90. XX wieku mamy obecnie do dyspozycji nowoczesne telefony komórkowe (tak zwane smartfony), które można podłączyć do telewizorów, komputerów, laptopów

${ }^{1}$ Posługuję się polską nazwą metody Wideotrening Komunikacji (WK) oraz równoważnymi określeniami używanymi w literaturze anglojęzycznej: Video Interaction Guidance (VIG), Video Interaction Training (VIT) oraz Video Home Training (VHT).

${ }^{2}$ Finansowanie szkoleń i wdrożenia metody WK zostało w całości zapewnione dzięki środkom holenderskiego Funduszu MATRA wspomagającego transformację krajów postradzieckich i zbliżenie ich do standardów zachodnioeuropejskich. 
itp. W pewnym sensie metoda wideofilmowania jako sposób komunikacji została zbanalizowana i zdegradowana przez szybki rozwój techniki (sprzętu) i technologii (oprogramowania, zapisywania, archiwizowania itp.). A jednak WK w dalszym ciągu służy jako narzędzie pomagania różnym kategoriom klientów (rodzicom dzieci z deficytami uwagi i nadmierną aktywnością, rodzicom dzieci z autyzmem czy niepełnosprawnością, rodzinom wieloproblemowym itp.), a co więcej odkrywane są nowe sfery jego zastosowania. Przykładem może być użycie WK w stomatologii; jego celem było polepszenie zrozumienia między lekarzami a niepełnosprawnymi pacjentami ( $\mathrm{z}$ upośledzeniami intelektualnymi i zaburzeniami komunikacyjnymi) w trakcie zabiegów dentystycznych (Quinn, Herron i in. 2016).

\section{Na czym polega Wideotrening Komunikacji?}

Podstawowe zasady pracy za pomocą WK są znane i dostępne dla osób zainteresowanych dzięki licznym publikacjom (między innymi: Miś 1999; Miś, Kujawa, Frysztacki 1999; Reczek, Miś 2001; Reczek 2016; Miś, Dąbrowska 2014, Dąbrowska 2019). Założenia aksjologiczne to: szacunek i zaufanie do klienta, nadzieja na zmianę, zaangażowanie, współpraca, wzajemne uznanie, więź i empatia. Są one w części tożsame z literą i duchem pracy socjalnej, a w części - bliskie, a na pewno niesprzeczne z pracą socjalną. Przekonania trenerów WK na temat natury ludzkiej są optymistyczne i pozytywne. Składają się na nie między innymi takie twierdzenia, jak:

- „ludzie mają wrodzoną potrzebę więzi z innymi;

- wszyscy ludzie - nawet w niesprzyjających okolicznościach - mają zdolność do zmiany;

- klienci muszą aktywnie włączać się w proces zmiany siebie;

- kluczem do wspierania klientów jest ich afirmacja i uznanie ich siły" (Kennedy, Landor i in. 2015).

Ten katalog wartości oraz założeń o potrzebach i działaniach ludzi został pierwotnie opracowany przez założycieli holenderskiego stowarzyszenia intensywnej opieki domowej SPIN. Był wtedy czymś nowym, ponieważ podejścia opierające się na silnych stronach klientów nie były jeszcze akceptowane i uznane przez profesjonalistów. Dominowało myślenie oparte na pojęciach deficytów, wad, patologii i problemów. Dopiero w następnych latach wyłoniły się koncepcje - posiadające obecnie największe znaczenie w brytyjskiej pracy socjalnej - czyli idee oparte na zasobach, sile klientów i ich odporności na destrukcyjne wydarzenia życiowe, kryzysy, traumy czy utraty (bliskich osób, pracy, miejsca zamieszkania, wiary, poczucia bezpieczeństwa itp.).

W latach 80. i 90. XX wieku, Wideotrening Komunikacji w sposób innowacyjny łączył osiągnięcia berlińskiej szkoły psychologii postaci, teorii uczenia się klasycznego i uczenia społecznego Alberta Bandury (Gens 2001). W okresie ostatniego dwudziestolecia w WK zostały inkorporowane wątki teorii budowania pozytywnych emocji oraz mentalizacji (Kennedy, Macdonald, Whalley 2016). Innymi słowy, Wideotrening 
Komunikacji możemy zaliczyć do podejść integracyjnych, charakterystycznych dla współczesnej pracy socjalnej, syntezujących to, co było najcenniejsze - chociaż czasami opozycyjne - na wcześniejszym etapie rozwoju nauki (na przykład podejście behawioralno-poznawcze, ekologiczno-systemowe czy humanistyczno-egzystencjalne - Miś 2019).

Wydaje się, że WK jest jednym z najbardziej skutecznych sposobów pomagania, ponieważ łączy trzy rzeczy: siły i zasoby rodziny/klienta, prosty schemat uczenia (czasami przeuczania) zachowań (tak zwana komunikacja podstawowa lub „zasady kontaktu”), który jest wynikiem głębokich i wyrafinowanych badań nad relacją matka-dziecko (Colwyna Trevarthena) oraz nowoczesną audiowizualną technologię. WK jest bardzo udanym, można użyć określenia „synergicznym”, połączeniem brytyjskiego empiryzmu i wysokiej jakości badań podstawowych z holenderską innowacyjnością i zaawansowaną techniką (produkcja sprzętu do nagrywania i odtwarzania filmów).

$\mathrm{W}$ pracy z klientami trenerzy posługują się schematem komunikacji podstawowej (tak zwane basic communication lub contact principles), który jest środkiem uczenia lub przeuczania rodziców w ich kontaktach z dziećmi. Mechanizm uczenia został opisany w pracy Hannelore Gens (2001). Opiera się on na budowaniu przestrzeni intersubiektywności w miejsce subiektywnych, zamkniętych w podmiocie myśli, wyobrażeń, emocji i działań. Zazwyczaj wyuczenie tego schematu i utrwalenie go wystarcza do osiągnięcia sukcesu, czyli nawiązania lub odbudowania więzi między rodzicami a dzieckiem (dziećmi). W przypadku rodzin wieloproblemowych lub większych trudności trenerzy również posługują się schematem określanym jako „plan pracy z rodziną”(„Trajekt Plan”). Składa się on z sekwencji pięciu etapów obejmujących: komunikację podstawową, życie codzienne (jego organizacja, rytuały, powtarzalne i niepowtarzalne działania), rozwój dziecka, rozwój rodziców i więź ze społecznością lokalną (sąsiadami, znajomymi, instytucjami pomocowymi i kontrolnymi, środowiskiem zawodowym itp.) (Reczek 2016). Komunikację podstawową i plan pracy z rodziną cechuje pewien porządek, który - podobnie jak wzór rozwoju intelektualnego dziecka w pracach Jeana Piageta - charakteryzuje się hierarchicznością. Nie można pracować na poziomie społeczności lokalnej, jeśli zostanie pominięty wcześniejszy etap, na przykład praca z rodzicami. Podobnie jest z komunikacją podstawową - nie można dyskutować i prowadzić wymiany w grupie, jeśli zostanie pominięty wcześniejszy etap „inicjatywy i odbioru tejże inicjatywy”. I odwrotnie, w przypadku konfliktu w grupie i nieudanych prób jego rozwiązania należy wrócić do tego, co najbardziej pierwotne i podstawowe: kontaktu wzrokowego czy też przyjemnego tonu głosu itp.

Ciekawa z socjologicznego punktu widzenia jest różnica w rozpowszechnieniu Wideotreningu Komunikacji, czyli Video Interaction Guidance (VIG) w Europie i USA. Wiele sposobów pracy (na przykład podejście skoncentrowane na rozwiązaniach czy interwencja kryzysowa) w równym stopniu są popularne po obu stronach Atlantyku. Natomiast w przypadku WK można mówić o znacznie większym jego rozpowszechnieniu w Europie i niewielkim w USA. Być może, podejście zrodzone i ukształtowane w Europie zbyt mocno odbiega od kultury pomagania i form instytucjonalnych przenikających działania pracowników socjalnych, trenerów, coachów czy doradców rodzinnych w USA. 


\section{Badania nad Wideotreningiem Komunikacji}

Wideotrening Komunikacji stał się przydatnym narzędziem w pracy z klientami, a badania dowodzą, że - w pewnej części - spełnia on wymagania praktyki pracy socjalnej opartej na dowodach (Evidence Based Practice). Ze zrozumiałych powodów większość badań nad WK to studia przypadków lub badania porównawcze, natomiast badania spełniające kryteria medycyny opartej na dowodach są o wiele rzadsze niż tradycyjne studia.

Spośród badań zrealizowanych w ostatnim dziesięcioleciu warto wymienić niektóre przykłady w celu zilustrowania, jak systematycznie prowadzony jest monitoring zastosowań metody w pracy z różnymi kategoriami klientów i w różnych warunkach instytucjonalnych.

Chociaż WK został pierwotnie użyty w innym kontekście, mianowicie domów dziecka i opieki zastępczej dla młodzieży, to wkrótce odkryto jego potencjał w pracy z rodzinami lub grupami z dziećmi albo młodzieżą z zaburzeniami ze spektrum autyzmu. Poszukiwanie sposobów pomocy tym rodzinom oraz silne społeczne wsparcie dla nich („tydzień autyzmu”, liczne medialne kampanie społeczne i prace naukowe oraz konferencje) wpłynęły na próby opracowania metodyki wideofilmowania i uczenia komunikacji podstawowej dla rodzin z dziećmi autystycznymi i wychowawców lub opiekunów w ośrodkach pomocy dla dorosłych osób z autyzmem.

Badanie Katie Gibson (2014) zostało pomyślane jako studium przypadku. Autorka pomagała rodzinie pełnej z dwójką dzieci (8 i 6 lat), z których jedno zostało zdiagnozowane jako osoba z zespołem Aspergera pół roku przed rozpoczęciem treningów wideo. Po zastosowaniu metody jej skuteczność została opisana - w konstrukcjonistycznej narracji - pod kątem postrzegania i doświadczania choroby przez rodziców oraz wpływu WK na relacje $z$ dzieckiem. Trening okazał się przydatny i pomocny rodzinie. Główne elementy zmiany, jaka nastąpiła, to stworzenie nowych i wzmacniających narracji wokół roli osoby z zespołem Aspergera, pełniejsze zrozumienie ludzi, którzy nie spotkali się z takimi przypadkami, bardziej adaptacyjne pełnienie ról rodzicielskich, odejście od monopolu medycznego myślenia o syndromie i zmniejszenie ryzyka wypalenia emocjonalnego w życiu rodzinnym.

Autorka stwierdziła, że „VIG ułatwił pogłębione badanie tego, jak tworzyć doceniające i pochwalane narracje wokół zespołu Aspergera, zbadał wyzwania stojące przed ludźmi, którzy nie znali tego syndromu, i wytworzenie roli rodzicielskiej przez matkę w kontaktach z innymi” [tłum. L.M.] (Gibson 2014).

Inne badania były prowadzone w ośrodku dla autystycznych dzieci i młodzieży. Pracownicy agencji byli początkowo bardzo niechętni do współpracy. Obawiali się ocen i krytyki ich sposobu pracy z klientami. Okazało się jednak, że niepokoje te udało się przezwyciężyć, a pracownicy stali się zwolennikami metody WK.

Nowa sfera zastosowań WK to praca z kobietami, które po urodzeniu dziecka cierpiały na depresję poporodową. Wzięły one udział w treningu, który u większości chorych doprowadził do zmniejszenia objawów depresyjnych. 
W tym miejscu należy przypomnieć, że jedną z pierwszych szczególnych form WK było tak zwane „kangurowanie” lub „metoda kangura” (Kangaroomethod) aplikowana w oddziałach neonatologicznych w sytuacjach, w których kontakt między rodzicami a dzieckiem był niemożliwy lub utrudniony. Typowe powody takiej sytuacji to zaburzenia rodziców (alkoholizm), wcześniactwo dziecka czy szczególne warunki pracy rodziców (rozłąka z dzieckiem u marynarzy, kierowców na trasach długodystansowych, emigrantów zarobkowych itp.).

Im wcześniejszy wiek dziecka, im większe znaczenie ma komunikacja bezsłowna między dzieckiem a rodzicem: za pomocą gestów, paramowy, postawy ciała, miejsca w przestrzeni, tym bardziej efektywna jest praca z użyciem WK.

$\mathrm{W}$ badaniu kobiet $\mathrm{z}$ depresją poporodową wzięły ostatecznie udział 22 osoby skierowane do programu VIG przez pracowników pomocy rodzinie (Family Support Service), lekarzy lub położne. Po zebraniu danych sprzed i po treningu okazało się, że większość jego uczestniczek zaobserwowała poprawę (zmniejszenie się objawów depresji poporodowej). Dodatkowe badania jakościowe pozwoliły stwierdzić, że uczestnictwo w programie WK umożliwiło lepsze zrozumienie dziecka i przyjemność z interakcji z nim, zwiększyło zaufanie do siebie jako matki i upodmiotowienie (Rackett, Macdonald 2014).

Typowe formy pracy socjalnej współcześnie dotyczą przemocy domowej i zaniedbania dzieci w rodzinach. Nina Maxwell i Alyson Rees (Uniwersytet Cardiff) zrobiły badania w ośrodku pomocy społecznej dzieciom (Children’s Services), w którym prowadzono pracę z rodzinami opierającą się na mocnych stronach klientów. Był on pod tym względem wyjątkowy, ponieważ dominujący sposób pracy z klientami w innych miejscach opierał się na założeniach menedżeryzmu i administrowania przypadkami. Wideotrening Komunikacji został zrealizowany w rodzinach, w których znajdowały się dzieci potrzebujące wsparcia socjalno-wychowawczego (większość) oraz dzieci wymagające ochrony i zapewnienia bezpieczeństwa. Uczestnicy WK zostali poproszeni o ocenę rezultatów po zakończeniu treningu, a następnie przeprowadzono badanie katamnestyczne po sześciu miesiącach. Uzyskano komplet odpowiedzi od trzynastu rodziców (trzech mężczyzn i dziesięciu kobiet). Okazało się, że najistotniejsze było pojawienie się relacji współpracy między rodzicami a trenerami, a następie uzyskanie świadomości tego, co należy zmienić $\mathrm{w}$ ich relacjach $\mathrm{z}$ dziećmi. „Fakt, że rodzice «zobaczyli się» $\mathrm{w}$ interakcji z dziećmi, był poruszający, a wizualny obraz pozostał z nimi, ponieważ, jak stwierdził jeden z uczestników, «faktycznie widzisz to, co robisz»" [tłum. L.M.] (Maxwell, Reese 2019: 1426). Warto podkreślić, że badania potwierdziły wcześniejsze ustalenia, że „krótsze programy pomocy - do sześciu sesji - były bardziej skuteczne niż te, które trwały dłużej". Warto ten wniosek zapamiętać i powoływać się na niego w dyskusjach na temat efektywności różnych metod pracy. W przypadku WK krótka interwencja jest bardziej skuteczna niż długa, klientom częściej wystarcza niewielka pomoc, żeby odzyskać podmiotowość i siły do radzenia sobie z trudnościami życiowymi.

Inne empiryczne świadectwa zmian pod wpływem WK pochodzą z Niderlandów (Lejda), Kanady (Quebeck), Finlandii, Norwegii i USA (Nowy Jork). Obejmowały one - odpowiednio - pomoc w modelowaniu dobrego rodzicielstwa, środowisko dzieci 
zaniedbanych i doświadczających przemocy, rodziny z trudnościami w komunikacji dzieci-rodzice oraz poradnictwo pediatryczne.

Oprócz badań pierwotnych spotykamy w literaturze przedmiotu coraz częściej analizy wtórne, opierające się na źródłach zastanych, czyli badaniach wykonanych kilka lub kilkanaście lat temu. Przykładem może być systematyczna metaanaliza danych przeprowadzona pod kierunkiem Stiny Balldin z Wydziału Pracy Socjalnej Uniwersytetu Lund (Szwecja). Objęła ona 29 badań zrealizowanych w latach 1990-2014 za pomocą wideofilmowania i udzielania informacji zwrotnej. Były wśród nich klasyczne studia nad VIG oraz badania innych form wideofilmowania, takie jak VIPP-SD (informacja zwrotna z użyciem wideo w celu wyuczenia bardziej pozytywnego rodzicielstwa i łagodnej dyscypliny), VIPP-TM (informacja zwrotna $\mathrm{z}$ użyciem wideo realizowana dla grup mniejszościowych - tureccy imigranci w Holandii), RFI (interwencja z użyciem wideo skoncentrowana na relacji) czy VTPP-Auti (wideointerwencja stosowana w pracy $\mathrm{z}$ dziećmi autystycznymi) itp. W badaniach poddano metaanalizie przypadki pracy w rodzinach $z$ dziećmi od pierwszego miesiąca do dwunastego roku życia, przy czym zdecydowana większość badań dotyczyła dzieci do trzeciego roku życia, a prośby o pomoc wideotrenerów pochodziły ze strony matek adopcyjnych, małoletnich matek, matek niewrażliwych na potrzeby dziecka lub mało empatycznych, mężczyzn, którzy po raz pierwszy zostali ojcami, matek z zaburzeniami jedzenia i depresją, rodziców znęcających się nad dziećmi i rodzin o wysokim ryzyku dysfunkcji. Konkluzje z badań były pozytywne, a badacze stwierdzili, że różne warianty użycia wideofilmowania i pracy z rodzicami na tej podstawie przyczyniły się do zwiększenia wrażliwości rodziców (lub matek) na potrzeby dzieci i poprawy zachowania dzieci. „Wyniki wskazują, że informacja zwrotna z użyciem kamery wideo jest skuteczna w odniesieniu do dzieci w różnym wieku i w środowiskach z rozmaitymi problemami i w grupach zróżnicowanych kulturowo" (Balldin, Fisher, Wirtberg 2018: 691).

Istnieją również ograniczenia i przeciwwskazania do stosowania WK. W odniesieniu do ośrodków realizujących pracę socjalną z użyciem wideotreningu Philip Heslop i Cathryn Meredith (2019: 163) stwierdzają, że „kultury organizacyjne nie były otwarte na twórcze formy interwencji. Wdrożenie WK wymaga wsparcia kierownictwa placówki i nie jest szybkim rozwiązaniem" [tłum. L.M.]. W naturalny sposób stanowi to limit w użyciu WK w niektórych instytucjach pomocowych, muszą one mieć władze zdeterminowane i przekonane o wartości WK, a pracownicy powinni przestawić się na podejście oparte na silnych stronach klienta i podkreślaniu pozytywnych elementów interakcji.

Stopniowo wzrasta liczba badań nad skutecznością WK. Należy zaznaczyć, że obejmują one zazwyczaj małe grupy (około dwudziestu kilku klientów) i - z etycznych oraz finansowych powodów - nie spełniają najwyższych rygorów badań naukowych (na przykład „podwójnej ślepej próby”).

W przeciwieństwie, choćby, do badań farmakologicznych (sprawdzających skuteczność różnych substancji chemicznych i lekarstw) czy nad nowoczesnymi technologiami medycznymi badania nad Wideotreningiem Komunikacji nie wiążą się z potencjalnymi przyszłymi zyskami. Klienci WK często korzystają z publicznych środków i uzyskują 
dofinansowanie na spotkania z terapeutą ze strony miasta, samorządu, organizacji pozarządowych czy państwa.

Z biegiem lat badań - realizowanych głównie w Holandii i Wielkiej Brytanii - jednak przybywa, więc baza empiryczna jest coraz bogatsza i zróżnicowana. Może warto przytoczyć w tym miejscu dwa rodzaje dowodów uzyskiwanych w trakcie badań.

Po pierwsze, WK jest czymś jakościowo innym niż samo używanie nagrań wideo do pracy z klientem. Porównywano grupy klientów, które korzystały z informacji zwrotnej przy użyciu nagrań wideo, oraz grupy, w których stosowano Wideotrening Komunikacji, czyli oprócz nagrań uczono rodziny klientów zasad komunikacji podstawowej i stosowano wartości oraz normy WK. Okazało się, że klienci WK po treningu wykazywali większe i bardziej pozytywne zmiany w interakcjach z osobami, na których im najbardziej zależało.

Po drugie, porównanie grupy, która przeszła WK, i grupy kontrolnej, w której nie stosowano żadnych form oddziaływania i pomocy w relacjach w bliskimi, dowiodło, że pierwsza grupa zmieniła swoje relacje z bliskimi (rodzicami, dziećmi) na lepsze i bardziej satysfakcjonujące.

Podsumowując, wkrótce po implementacji metody do pracy socjalnej i edukacji rozpoczęły się badania nad jej użytecznością. Pierwszymi badaczami, którzy podjęli ten temat, byli: Paul Wels z Uniwersytetu Nijmegen i Rianne Jansen. Początki ich badań sięgają lat 90. XX wieku i były one kontynuowane w następnych dekadach, czyli ich historia liczy ćwierć wieku. Podobnie było z Marij Eliens, która zainteresowała się problemem nadmiernie płaczliwych dzieci (niemowląt) i również pracowała dalej nad tym tematem w następnym dziesięcioleciu ${ }^{3}$. W Czechach uczestniczki kursów popularyzujących metodę wykorzystały swoją wiedzę i napisały prace magisterskie na jej temat ${ }^{4}$.

W ostatnich piętnastu latach pojawiły się prace badawcze poświęcone WK. Przykładem jest praca dyplomowa Franziski Meier i Manuela Neubachera (2008). Doktorskie dysertacje zostały stworzone w ramach odrębnych dyscyplin: psychologii (Alghali 2019; Collins 2013) czy pedagogiki (Newbery 2015). Autorzy ci podjęli próbę ewaluacji przydatności WK w odniesieniu do rodzin z dziećmi autystycznymi, niepełnosprawnymi intelektualnie oraz niedosłyszącymi i głuchymi. Wyniki ich badań dowodzą pozytywnego wpływu WK na uczestników programów, wskazują na korzyści, jakie oni odnieśli, oraz ograniczenia zastosowań metody ze względu na uwarunkowania instytucjonalne i metodyczne.

${ }^{3}$ Niestety, większość prac na temat badań P. Welsa i R. Jansen jest dostępna w języku niderlandzkim. Wyjątkiem są ich publikacje w języku angielskim (Wels 2004). Natomiast bogata literatura na temat VIG w języku angielskim jest przede wszystkim dziełem Hilary Kennedy i jej współpracowniczek.

${ }^{4}$ Przykładem są prace magisterskie Petry Koberskiej czy Hany Jelinkovej obronione na Uniwersytecie Karola w Pradze. 


\section{Stowarzyszenia i organizacje praktykujące i promujące WK}

Wideotrening Komunikacji pojawił się w Holandii i Wielkiej Brytanii w latach 80. XX wieku. Zgodnie z ówczesną tamtejszą filozofią pomagania i liberalną polityką społeczną miejscem dla praktykowania WK stały się organizacje pozarządowe. Niektóre z nich miały formę fundacji, inne zaś - profesjonalnych stowarzyszeń (poradnictwa, terapii, coachingu itp.). Pierwszą była macierzysta niderlandzka fundacja SPIN (Stichting Promotie Intensieve Thuisbehandeling), na której oparła się powstała później AIT (Associatievoor Interactiebegeleiding en Thuisbehandeling). Następnie pojawiły się krajowe stowarzyszenia w innych krajach: w Wielkiej Brytanii (AVIGuk - Association for Video Interaction Guidance United Kingdom), w Niemczech (DGVB - Deutsche Gesellschaft fuer Vidobasierte Beratung ${ }^{5}$ ), w Czechach, Danii, Polsce (VIT-SPIN Polska), na Węgrzech czy w USA (SPIN USA Inc. - National Institute Video Interaction Guidance).

Inne metody podobne do WK i organizacje je promujące to metoda Marty Meo (dzieło Marty Aarts) czy VIPP - metoda uczenia pozytywnego rodzicielstwa i łagodnej dyscypliny (Uniwersytet w Lejdzie). Należy wskazać w tym miejscu, że sprawą istotną dla rozwoju jest nie tylko powołanie do życia profesjonalnego stowarzyszenia zajmującego się standardami pracy i programem szkolenia, lecz także współpraca między tymi stowarzyszeniami a ośrodkami badawczymi na uniwersytetach (na przykład w Nijmegen, Lejdzie czy Dundee).

\section{Zakończenie}

Na początku niniejszego tekstu przywołałem połowę lat 90. XX wieku jako czas, w którym pojawiły się ważne inicjatywy i prace organizacyjne dla pracy socjalnej. Wydaje mi się, że minione ćwierć wieku jest dobrą okazją do podsumowania. Skupiłem się przede wszystkim na zmianach, jakie nastąpiły w zakresie innowacyjnej podówczas metody Wideotreningu Komunikacji w niektórych krajach europejskich, w tym w Polsce. Zmiany te można określić jako rozwój, ponieważ WK stał się narzędziem pracy, które znajdowało zastosowanie w rosnącej liczbie praktyk pomocowych (praca socjalna, psychologia wychowawcza, pedagogika, pielęgniarstwo, stomatologia oraz superwizja trenerów we wszystkich tych dziedzinach). Można mówić też o przestrzennej ekspansji metody: począwszy od Niderlandów i Szkocji, poprzez Anglię, Niemcy, Czechy, Polskę, Węgry, do Finlandii i Stanów Zjednoczonych Ameryki. Można zatem stwierdzić, że WK rozwijał się horyzontalnie, a ponadto wertykalnie (kumulacja doświadczeń, instytucjonalizacja i certyfikacja, monitorowanie i poddawanie systematycznym badaniom naukowym). Godne podkreślenia jest mocne osadzenie WK jako narzędzia pomocnego nauczycielom

${ }^{5}$ DGVB prowadzi działalność w sześciu krajach związkowych Republiki Federalnej Niemiec i jest członkiem instytucjonalnym niemieckiego stowarzyszenia systemowej terapii rodzinnej (Deutsche Gesellschaft für Systemische Therapie, Beratung und Familientherapie). 
w pracy z uczniami szkół podstawowych, a nawet średnich (Hayes, Richardson, Hindle, Gravson 2011; Jilink, Fukkink, Huijbregts 2018).

Wideotrening Komunikacji był innowacyjną metodą pomocy rodzinom i środowiskom z klientami wieloproblemowymi, niepełnosprawnymi, z trudnościami komunikacyjnymi, rozdzielonymi fizycznie czy klientami z rodzin imigranckich i mniejszości etnicznych. Okazało się jednak, że to twórcy metody swoimi ideami wybiegli w przyszłość, a zmiany w technice, rodzinach i w społeczeństwie nadeszły później. Dziś dysponujemy wyrafinowaną technologią wideorejestracji, analizy materiału filmowego, a nawet obróbki cyfrowej. Z tego powodu poszerzyła się liczba organizacji i praktyków stosujących WK. W najbardziej usystematyzowany i wszechstronny sposób WK jest praktykowany w psychologii wychowania (Kennedy i jej współpracownicy oraz uczniowie w Szkocji), najczęściej w postaci wykonywania wolnego zawodu (tak zwany free lance) lub w ramach stowarzyszeń i fundacji. Wydaje się to zrozumiałe, ponieważ idea i schemat komunikacji podstawowej zostały opracowane na Uniwersytecie w Edynburgu (Szkocja).

Wideotrening Komunikacji - pomimo ułatwień, jakie przyszły wraz z rozwojem technologii informatyczno-komunikacyjnych (głównie smartfony, lecz również zminiaturyzowane kamery wideo i aparaty fotograficzne) - nie stał się metodą pracy z rodzinami lub grupami (np. pensjonariuszami domów opieki) w większości krajów europejskich. Główne ośrodki to wciąż Holandia (Utrecht i Lejda) i Wielka Brytania (z przodującym ośrodkiem w Szkocji), Niemcy, Dania, Finlandia, Czechy (Praga), Polska i Węgry. Brakuje doniesień w czasopismach czy książkowych publikacjach naukowych i profesjonalnych o stanie i rozwoju WK w innych krajach. Podobnie sytuacja wygląda w USA, gdzie rozpoczęto wdrażanie metody i włączanie jej do praktyki placówek opieki nad dziećmi i edukacyjnych pod koniec lat 90., głównie w stanie Massachusetts i Kalifornia. Do chwili obecnej pozostaje aktywne stowarzyszenie SPIN USA, krajowe centrum VIG/ VHT założone przez Jane Nestel-Patt w Lexington (MA), oferujące pomoc dla rodzin z mniejszości etnicznych oraz szkolenia w ramach superwizji i zarządzania personelem.

Na początku stosowania metody WK przeszkodą były bariery mentalne, zwyczaje i tradycyjne określenie sfery prywatności. Dość naturalny był fakt, że WK pojawił się w Holandii, gdzie normą jest przejrzystość życia rodzinnego i jawność tego, co dzieje się $\mathrm{w}$ domu (niezasłonięte okna w domach, liberalizm obyczajowy), oraz otwartość na innowacje społeczne i techniczne, a także nowe formy zachowania. W ostatnim dziesięcioleciu dokonała się jednak rewolucja związana z robieniem sobie zdjęć (tak zwanych selfie) i uwiecznianiem wielu momentów życia rodzinnego, sąsiedzkiego i koleżeńskiego. Granice pokazywania się publicznie (przede wszystkim w sieciach społecznościowych) przesunęły się bardzo daleko. Dzieci i młodzież oraz ich rodzice oswoili się z prywatnym wideofilmowaniem i rozpowszechnianiem treści audiowizualnych wśród znajomych, a nawet nieznajomych. Zmiana tych norm i obyczajów powinna - teoretycznie - sprzyjać popularyzacji metody i osłabieniu oporów klientów przed nagrywaniem scenek z życia rodzinnego.

W Polsce najbardziej rozwinięte ośrodki praktykowania WK i podobnych wariantów pracy z użyciem wideokamery znajdują się w takich miejscach, jak Kraków i okolice 
(Maltańskie Centrum Pomocy Niepełnosprawnym Dzieciom i Ich Rodzinom oraz filie ośrodków pomocy społecznej), Poznań i Bydgoszcz.

WK stał się też jedną z uznanych metod pracy socjalnej, obecną we współczesnych zagranicznych podręcznikach i monografiach. Za przykłady mogą służyć: rozdział Kateriny Beaufortovej w podręczniku Oldricha Matouska (2008), prace Juliet Koprowskiej (2014) czy Heslopa i Meredith (2019).

Warto tu przypomnieć, że początki pracy socjalnej polegały na spotkaniu klientów w ich mieszkaniach, na ich terenie i w ich naturalnym środowisku społecznym. Były to "przyjacielskie odwiedziny” ludzi biednych i pozbawionych zaplecza życiowego (imigrantów, samotnych, opuszczających zakłady karne i psychiatryczne). Ten kluczowy mechanizm jest również podstawową częścią WK. „Oparta na odwiedzeniu domu istota WK wydaje się mieć kluczowe znaczenie dla interwencji. Ze względu na charakter klientów instytucji pomocowej i ich tendencje do chaotycznego życia WK oferuje usługę domową zachęcającą do wyższego poziomu zaangażowania zarówno ojców, jak i matki” (Maxwell, Rees 2019: 1426).

W 2019 roku możemy stwierdzić po ćwierćwieczu, że WK przyjął się i upowszechnił w działalności pomocowej i usługach socjalnych oraz medycznych w niektórych krajach Unii Europejskiej (Holandia, Wielka Brytania, Niemcy, Czechy, Polska, Węgry, Dania, Finlandia) i w kilku stanach USA (Massachusetts, Kalifornia), w innych zaś - nie (na przykład w południowych krajach Unii Europejskiej). Znaczący jest fakt opatentowania metody w krajach anglosaskich i w Niemczech oraz uzyskanie prawnej ochrony - za pomocą znaku handlowego „Trade Mark” - tego sposobu pracy. Dlatego możemy mówić o prywatyzacji i komercjalizacji WK, co w pewnych miejscach i kontekstach instytucjonalnych stoi w sprzeczności z wartościami i zasadami pracy socjalnej w niektórych krajach. Jest równocześnie dowodem na poszanowanie własności intelektualnej i próbą ustanowienia standardów pracy.

W niektórych krajach (głównie anglosaskich) sprzeczności między wartościami pracy socjalnej a komercjalizacją metody nie ma $\mathrm{z}$ uwagi na legalizację prywatnej praktyki pracowników socjalnych. Kształcenie w zakresie metody uległo zatem formalizacji i standaryzacji oraz regulacji ustawowej. Na przykład, w Wielkiej Brytanii Video Interaction Guidance uzyskał akredytację odpowiednich ciał nadzorczych jako jedna $\mathrm{z}$ dwóch rekomendowanych metod pracy $\mathrm{z}$ rodzinami.

Ponadto WK okazał się przydatny w instytucjach pomocowych, takich jak ośrodki dla osób z zaburzeniami ze spektrum autyzmu, placówki pomocy społecznej (osoby niepełnosprawne, osoby niedosłyszące lub głuchonieme, osoby z zaburzeniami neurodegeneracyjnymi).

Obecnie WK ma dobrze zakreślony obszar i zakres wskazań do stosowania, podobnie jest z przeciwwskazaniami do jego użycia. Nie jest uniwersalną metodą, odpowiednią do stosowania przez pracowników socjalnych w odniesieniu do wszystkich przypadków. Co więcej, w placówkach nastawionych na zarządzanie przypadkami, pozbawionych kierownictwa akceptującego nowości i krótkoterminową pracę z klientami budującą 
poczucie pewności siebie klientów, wprowadzenie Wideotreningu Komunikacji ma niewielkie szanse na powodzenie.

WK był pierwszym, dobrze opracowanym pod względem teoretycznym (teoria intersubiektywności Colwyna Trevarthena) i metodycznym sposobem pomagania w naturalnym środowisku klientów. Zrozumiałe jest, że sukces metody zachęcił do zwiększenia spektrum oddziaływań pracowników socjalnych, psychologów i pedagogów z wykorzystaniem nagrań i analizy wideo. Przykładami są tu VERP czy VIPP Video Feedback Intervention to Promote Positive Parenting Uniwersytetu w Lejdzie oraz inne. Sukces w użyciu WK leży w spełnieniu warunku, jakim jest otwarta, sprzyjająca innowacjom kultura organizacji, w której realizowany jest program pomocy z użyciem wideofilmowania.

\section{Bibliografia}

Alghali H. (2019). Professionals' perception of the process of change during an attachment based parenting intervention (Video Interaction Guidance) with parents with intellectual disabilities. Praca doktorska, University of London, London.

Balkom H. van, Verhoeven L., Weerdenburg M. van, Stoep J. (2010). Effects of Parent-Based Video Home Training in children with developmental language delay. „Child Language Teaching and Therapy", 26, 3: 221-237.

Balldin S., Fisher P.A., Wirtberg I. (2018). Video Feedback Intervention with Children: A Systematic Review. „Research on Social Work Practice”, 28 (6): 682-695.

Beaufortova K. (2008). Videotrenink interakcji, w: O. Matousek i in., Metody a rizani socialni prace. Portal, Praha.

Celebi M. (2014). How Video Interaction Guidance can promote attuned parenting. „Journal of Health Visiting", 2, 2.

Collins L.C. (2013). Exploring empowerment in conversation: Delivering Video Interaction Guidance to families of children who are deaf or hard of hearing. Praca doktorska, University of Nottingham, Nottingham.

Dąbrowska B. (2019). „Nowa” praca socjalna, w: K. Frysztacki (red.), Praca socjalna. 30 wykładów. Wydawnictwo Naukowe PWN, Warszawa: 400-421.

Doria M.V., Kennedy H., Strathie C., Strathie S. (2013). Explanations for the Success of Video Interaction Guidance (VIG): An Emerging Method in Family Psychotherapy, „The Family Journal", 22 (I): 78-87.

Eliens M. (2005). Babies in the Picture: The Effect of Video Home Training and Video Interaction Guidance for Parents with Babies who Excessively Cry. AIT/De Combinatie, Amsterdam.

Fukking R.G. (2008). Video feedback in widescreen: A meta-analysis of family programs. „Clinical Psychology Review", 28: 904-916.

Gens H. (2001). VHT - dlaczego pracujemy właśnie tak, w: E. Reczek, L. Miś (red.), Z teoretycznych i metodologicznych zagadnień Wideotreningu Komunikacji. Instytut Socjologii UJ, Kraków. 
Gibson K.A. (2014). Appreciating the world of autism through the lens of Video Interaction Guidance: An exploration of a parent's perceptions, experiences and emerging narratives on autism. „Disability and Society”, 29, 4: 568-582.

Haggman-Laitila A., Pietila A.-M., Friis L., Vehvilainen-Julkunen K. (2002). Video Home Training as a method of supporting family life control. „Journal of Clinical Nursing”, 12, 1.

Haggman-Laitila A., Seppanen R., Vehvilainen-Julkunen K., Pietila A.-M. (2010). Benefits of Video Home Training on families' health and interaction: Evaluation based on follow-up visits. „Journal of Clinical Nursing”, 19 (23-24): 3504-3515.

Hayes B., Richardson S., Hindle S., Gravson K. (2011). Developing teaching assistants' skills in positive behaviour management: An application of Video Interaction Guidance in a secondary school. „Educational Psychology in Practice”, 27, 3: 255-269.

Hayes B., Dewey J., Sancho M. (2014). Using Video Interaction Guidance to Develop Intrapersonal and Interpersonal Skills in Professional Training for Educational Psychologists. „International Journal of Teaching and Learning in Higher Education”, 26, 3: 436-444.

Heslop Ph., Meredith C. (2019). Social Work: From Assessment to Intervention. SAGE, London. Jelinkova H. (2012). Wideotrenik interakcji a moznost jako wyużitiv programach primarni prevence. Karlova Univerzita, Praha.

Jilink L., Fukkink R., Huijbregts S. (2018). Effects of early childhood education training and Video Interaction Guidance on teachers' interactive skills. „Journal of Early Childhood Teacher Education", 39, 4: 278-292.

Kennedy H., Landor M., Todd L. (red.) (2011). Video Interaction Guidance: A Relationship-Based Intervention to Promote Attunement, Empathy and Wellbeing. Jessica Kingsley Publishers, London.

Kennedy H., Landor M. i in. (2015). Video Enhanced Reflective Practice: Professional Development Through Attuned Interactions. Jessica Kingsley Publishers, London.

Kennedy H., Macdonald M., Whalley P. (2016). Video Interaction Guidance. Providing effective response for neglected children, w: R. Gardner (red.), Tackling Child Neglect: Research, Policy and Evidence-Based Practice. Jessica Kingsley Publishers, London-Philadelphia, Pennsylvania.

Koprowska J. (2014). Communication and Interpersonal Skills in Social Work. SAGE, Glasgow. Matousek O. i in. (2008). Metody a rizani socialni prace. Portal, Praha.

Maxwell N., Rees A. (2019). Video Interaction Guidance: A Return to Traditional Values and Relationship-Based Practice?. „British Journal of Social Work”, 49: 1415-1433.

Meier F., Neubacher M. (2008). Kamera in Wohnzimmer - Einequalitative Befragung von Elternzum Video Home Training in der Erziehungsberatung. Praca licencjacka, Zürcher Hochschule für Angewandte Wissenschaften, Bern und Zürich.

Miś L. (1999). VHT/VIG, czyli domowy trening komunikacji. „Problemy Rodziny”, XXXIX, 5-6 (227-228). Towarzystwo Rozwoju Rodziny, Warszawa: 46-49.

Miś L. (2019). Wachlarz współczesnych stanowisk teoretycznych dla pracy socjalnej, w: K. Frysztacki (red.), Praca socjalna. 30 wykładów. Wydawnictwo Naukowe PWN, Warszawa: 97-117.

Miś L., Dąbrowska B. (2014). Rodzina jako problem, rodzina jako rozwiązanie. „Zeszyty Pracy Socjalnej” 19 (4). Wydawnictwo Uniwersytetu Jagiellońskiego, Kraków: 12-132. 
Miś L., Kujawa M., Frysztacki K. (1999). Video Home Training jako metoda pracy z rodzinami, w: M. Malikowski (red.), Praca socjalna i pomoc społeczna. Aspekty teoretyczne - Kształcenie - Aplikacja. Wydawnictwo WSP, Rzeszów.

Newbery H.V. (2015). Video Interaction Guidance: Exploration of the experiences of two parent-child dyads. Praca doktorska. University of Birmingham, Birmingham.

Quinn S., Herron D., Menzies R., Scott L., Black R., Zhou Y., Waller A., Humphris G., Freeman R. (2016). The Video Interaction Guidance approach applied to teaching communication skills in dentistry. „European Journal of Dental Education”, 20, 2: 94-101.

Rackett P., Macdonald B. (2014). 'Fun with Mum': Using Video Interaction Guidance to enhance early relationships and diminish maternal postnatal depression. „Educational and Child Psychology", 31, 4: 82-92.

Reczek E. (2001). Wprowadzenie, w: E. Reczek, L. Miś (red.), Z teoretycznych i metodologicznych zagadnień Wideotreningu Komunikacji. Instytut Socjologii UJ, Kraków.

Reczek E. (2016). Wideotrening Komunikacji w pracy $z$ rodzina $z$ dysfunkcjami $w$ petnieniu funkcji rodzicielskiej, w: I. Krasiejko, M. Ciczkowska-Giedziun (red.), Praca socjalno-wychowawcza z rodzing w ujęciu wybranych koncepcji. Instytut Rozwoju Służb Społecznych, Warszawa: 91-105.

Reczek E., Miś L. (red.) (2001). Z teoretycznych i metodologicznych zagadnień Wideotreningu Komunikacji. Instytut Socjologii UJ, Kraków.

Sirova E., Krejcova K. (2011). The Role of the Video Interaction Guidance in the Enrichment of Student Teachers' Social Skills. „Journal on Efficiency and Responsibility in Education and Science", 4, 4: 162-169.

Trevarthen C. (2011). Confirming companionship in interests, intentions and emotions, w: H. Kennedy, M. Landor, L. Todd (red.), Video Interaction Guidance: A Relationship-Based Intervention to Promote Attunement, Empathy and Wellbeing. Jessica Kingsley, London.

Wels P.M.A. (2004). Helping with a Camera. Universiteit Nijmegen, Nijmegen. 